\title{
Body Composition Characteristics Measured By Multichannel Bioimpedance In Young Female Basketball Players: Relation With Match Performance
}

\author{
Características de la Composición Corporal Medidas por Bioimpedancia Multicanal \\ en Jugadoras de Baloncesto Jóvenes: Relación con el Rendimiento del Partido
}

Ivan Zaric ${ }^{1}$; Milivoj Dopsaj ${ }^{1,3}$; Milan Markovic ${ }^{1}$; Milan Zaric ${ }^{1}$; Sasa Jakovljevic ${ }^{1} \&$ Dragana Beric $^{2}$

ZARIC, I.; DOPSAJ, M.; MARKOVIC, M.; ZARIC, M.; JAKOVLJEVIC, S. \& BERIC, D. Body composition characteristics measured by multichannel bioimpedance in young female basketball players: relation with match performance. Int. J. Morphol., 38(2):328335,2020 .

SUMMARY: The aim of this research is to investigate the correlation of morphological characteristics, that is, body composition characteristics with the competitive performance of female basketball players of cadet (U16) age, in general and depending on the position played in the basketball team. The research involved female basketball players from the U16 section of the three best basketball clubs from the First Cadet League of Serbia $(\mathrm{N}=30)$. This research consisted of measuring the characteristics of body composition, as a space of independent variables and the analysis of competitive activities where the dependent variable represents the level of achieved competitive performance. Based on the results of the Pearson Correlation Analysis, which was made for determining the degree of connection between the dependent variable and the independent variables, it can be seen that general level competitive performance is associated with the variables: percentage skeletal muscle mass, index of hypokinesy and protein-fat index. Viewed from the point of the position played in the team, the statistically significant relationship between the independent and the dependent variable was recorded only in the forwards position. Competitive and more successful forward players are distinguished by a small percentage of body fat mass, a higher percentage of muscle mass, a smaller hypokinesy index and a larger protein-fat index. The practical application of this research can be seen in the control system of applied training work, then selection, as well as in the creation of a model for morphological characteristics of players in the cadet (U16) age.

KEY WORDS: basketball; performance index rating; women athletes; morphology; anthropometry.

\section{INTRODUCTION}

Basketball training methods are aimed at achieving results through the development of the sporting form. However, there is no optimal management of training technology unless we know all the factors on which competition performance depends. Prior to the operational stage in training technology, the question is what are the skills, abilities and characteristics on which the sports result depends? If this is unknown, managing the basketball training process is inefficient and belongs to the category of stochastic processes. Only after determining the dominant factors that have an effect on basketball performance can it be applied to deterministic training programming. It is impossible to form a successful training programme if there is no information about the factors on which competing efficiency and competing performance depends.
The optimal competitive performance for female or male basketball players depends on a combination of technical and tactical skills and an adequate level of physical fitness (Ziv \& Lidor, 2009), as well as morphological characteristics (Hoare, 2000; Garcia-Gil et al., 2018). The study of the morphological characteristics of top athletes makes it possible to create a notion of how athletes should look in certain sports disciplines (Carter et al., 2004). A good knowledge of the morphological characteristics of athletes who achieve top results can form a model, which then directs the selection and training process. Different sports disciplines determine the development of various morphological characteristics, so basketball requires the same kind of specificity (Ochoa Martínez et al., 2014), and should define the given standards.

\footnotetext{
${ }^{1}$ Faculty of Sport and Physical Education, University of Belgrade, Serbia.

${ }^{2}$ Faculty of Sport and Physical Education, University of Nis, Serbia.

${ }^{3}$ Institute for Sport, Tourism and Service, South Ural State University, Chelyabinsk, Russia.
} 
When considering the training processes of young basketball players it is important to monitor information from the morphological area. During the growth and development of children, certain parts of the body have different dynamics of growth and reach maximum growth at different points in time. For these reasons, the morphological structure of the basketball player's body is not identical at all stages of development. Therefore, some morphological characteristics can be utilised at different time points, with different coefficients of participation in the morphology of basketball players (Norton \& Olds, 2001; Malina et al., 2004).

One of the basic goals in forming a top athlete is to provide the athlete with a long-term training programme aimed at allowing them to achieve, as much as possible, their biological potential in terms of the development of morphological, physical, psychological, technical and tactical abilities (Zaricet al., 2018). One of the most characteristic, but at the same time the most sensitive periods in an athlete's development, is the end of puberty and the beginning of serious training work, which includes an increase in specific training methods and specific loads (Bompa \& Buzzichelli, 2015). For this reason, it is important for sports theory and the practice of basketball, to define the quantitative relationships between competitive performances in terms of performance index rating (PIR). This is the most frequently observed statistical parameter in basketball that shows the competitive performance of female basketball players (Sampaio et al., 2006; Ibáñez et al., 2009) and is therefore vital for the selection system and determining morphological characteristics, which are both important for the training process of basketball players. Such data are essential in terms of correcting and programming the training process, but also for defining all norms and standards in the athletes' testing system (Tanner \& Gore, 2013). The performance statistics of the players in the match also depend on the player's position in the team, probably due to different anthropometric parameters (Sampaio et al.). In view of this, it is necessary to determine the anthropometric characteristics, that is, the body composition characteristics that influence the competitive performance of the various positions played in the basketball team.

Based on previous research, the importance of morphological characteristics of female and male basketball players for achieving success in basketball is clear. The dominant characteristic for success in basketball is the longitudinal dimension of the skeleton, followed by the transversal dimension of the skeleton and body mass. In view of the specific structure of basketball, subcutaneous fat tissue appears strongly as a negative feature, that is, a factor that distorts the competitive activity of female and male basketba11 players (Ziv \& Lidor; Pehar et al., 2017; Garcia-Gil et al.; Ramos et al., 2018).
It is obvious that there is an extremely complex relationship between competitive performances in relation to the different morphological characteristics of basketball players. As women's basketball has the status of an Olympic sport, with an entire system of national, continental and intercontinental competitions, there is a necessity for having a technologically and methodologically designed long-term training programme for the players. In this sense, the aim of this work is to investigate the correlation of morphological characteristics, that is, body composition characteristics with the competitive performance of basketball players. The study covers players of cadet age (U16) at general level, along with their position in the basketball team (guards, forwards and centre). This is the first age category where the training processes become integrated with the league competition and in accordance with the senior rules.

\section{MATERIAL AND METHOD}

Experimental Approach. The study design used in this research is Cross-Sectional Designs. It is applied according to the standards of research methods in physical activity and sports (Thomas et al., 2015). This research consisted of measuring the characteristics of body composition, as the space of predictive (independent) variables and analysis of competitive activities where the criterion (dependent) variable represents the level of achieved competitive performance.

Sample of Subjects. This research involved 30 female basketball players (12 from guard positions, 11 from forward positions and 7 from the centre position) at cadet (U16) level, with average age $14.98 \pm 0.68$ years. Players selected are from the top three basketball clubs in the First Cadet League of Serbia. The research was carried out in accordance with the conditions of the "Declaration of Helsinki for Recommendations Guiding Doctors in Biomedical Research involving Human Subjects" - (http://www.cirp.org/library/ ethics/helsinki/), and with the approval of the Ethics Commission of the Faculty of Sport and Physical Education, University of Belgrade.

Procedure. Morphological testing lasted one day and conducted in the main competition mesocycle of the season. All measurements were collected between 8:00 a.m. and 10:00 a.m. at the Methodological Research Laboratory of the Faculty of Sports and Physical Education of the University of Belgrade. The sample of basketball players were instructed not to eat food or take liquid before the measurements and to avoid long-term and hard physical or sports activities in the day preceding the measurements. All 
measurements were carried out by specialists who are trained and have experience of the following measuring instruments, using standardised procedures (anthropometer by Martine and Multichannel segmental bioimpedance method (InBody 720)). The sample of players first had their body height measured, followed by measurement on InBody 720. The independent variables from the morphological characteristics area were: body height $(\mathrm{BH})$, body mass $(\mathrm{BM})$, body mass index (BMI), body fat mass (BFM), skeletal muscle mass (SMM), percentage body fat mass (BFM\%), percentage skeletal muscle mass (SMM\%), body fat mass index (BFMI), skeletal muscle mass index (SMMI), index of hypokinesy (IH), protein (PROTEIN), protein-fat index (PFI) (Dopsaj et al., 2017; Bankovic et al., 2018; Kukic et al., 2018).

The basketball players' match performance analyses were based on statistics provided by unified Serbian Women Basketball League Under-16 about the individual performance of each player (http://www.kss.rs). The analysis comprises four matches out of which the first one was seven days prior to testing, second one three days prior to testing, third one three days after the testing and fourth one seven days after the testing.

BH - Measurement was conducted with an anthropometer by Martin (GPM, model 100, Seritex, Swiss). In this measurement, the basketball player was barefoot, in underwear and standing in an upright position on a solid horizontal surface. The player's head was in such a position that the Frankfurt plane was horizontal. During the measurement, she straightened her back as far as possible and put her feet together. The person measuring was standing to the left side of the player and controlled whether the anthropometer was positioned directly along the back of the body vertically, allowing it to partially grasp the body. They then lower the metal slider so that the horizontal crossbar meets the top of the head of the basketball player.

BM, BFM, SMM, PROTEIN - Measurement was done using the Multi-Channel Segmental Bioimpedance method (InBody 720, Cerritos, USA). The procedure for using the InBody 720 instrument required basketball players to be exclusively in their underwear during their testing, without jewellery or watches. The basketball players would stand on the platform and take the movable handles in their hands. With their elbows fixed and arms straight down beside the body, they were required to stand until a sound indicated the end of the measurement. For the measurement of variables, the bioelectrical impedance uses electrical waves of different frequency levels, where each individual frequency corresponds to the values of the corresponding target variable.
BFM\%, SMM\%, BFMI, SMMI, BMI, IH, PFI Derived variables obtained as follows: $\mathrm{BFM} \%=(\mathrm{BFM} /$ $\mathrm{BM}) \times 100 ; \mathrm{SMM} \%=(\mathrm{SMM} / \mathrm{BM}) \times 100 ; \mathrm{BFMI}=\mathrm{BFM} /$ $((\mathrm{BH} / 100) \times(\mathrm{BH} / 100)) ; \mathrm{SMMI}=\mathrm{SMM} /((\mathrm{BH} / 100) \times$ $(\mathrm{BH} / 100)) ; \mathrm{BMI}=\mathrm{BM} /((\mathrm{BH} / 100) \times(\mathrm{BH} / 100)) ; \mathrm{IH}=$ $\mathrm{BFM} \%$ / BMI; PFI = PROTEIN / BFM.

Match Performance Analysis (MP) - The performance index was calculated on the basis of the various parameters of situational performance. The performance index rating was calculated according to the following formula: PIR = [(number of 3-point shots scored $\times 3+$ number of 2-point shots scored $\times 2+$ number of free-throw shots scored + number of assists + number of rebounds + number of 'steals' + number of personal fouls made on the player + number of blocks) - (number of 3-point shots missed + number of 2-point shots missed + number of free-throw shots missed + number of personal fouls + number of technical fouls + number of turnovers + number of shots by the player blocked by an opponent)] / number of games. The measured variable is the average performance index in the four games played in the Championship (Zaric et al.).

Statistical Analyses. All raw data were first analysed using basic descriptive statistical methods to calculate mean values, standard deviation, minimum, maximum, variation coefficient and upper and lower confidence interval. Pearson Correlation Coefficient was used to determine the degree of connection between the dependent variable (variables of competitive performance) and independent variables (variables of morphological characteristics). All statistical analyses were calculated using SPSS 22.0 software, while statistical significance was defined at $95 \%$ probability, for $\mathrm{p}<0.05$.

\section{RESULTS}

The results of the basic descriptive statistics are presented as a general level (all players) and in groups depending on the position in the basketball team (Table I, II, III and IV). At the general level, variables in the percentage of skeletal muscle mass, the index of hypokinesy and protein-fat index statistically significantly correlate with the dependent variable $(\mathrm{SMM} \% \mathrm{r}=0.40, \mathrm{p}=0.03$; $\mathrm{IH} \mathrm{r}=-0.43, \mathrm{p}=0.02$; PFI $r=0.36, p=0.05$, Table $V)$. In the groups made up of the position in the team, the statistical significance between the independent and the dependent variable was recorded only in the forwards and in independent variables percentage fat mass, percentage skeletal muscle mass, index of hypokinesy and protein-fat index $(\mathrm{BFM} \% \mathrm{r}=-0.65, \mathrm{p}=0.03 ; \mathrm{SMM} \% \mathrm{r}=$ $0.72, \mathrm{p}=0.01 ; \mathrm{IH} \mathrm{r}=-0.81, \mathrm{p}=0.00$; PFI $\mathrm{r}=0.74, \mathrm{p}=0.01$; Table V; Fig. 1 and 2). 
Table I. Descriptive statistics - All players (positions 1, 2, 3, 4 and 5).

\begin{tabular}{|c|c|c|c|c|c|c|c|}
\hline & \multirow[b]{2}{*}{ MEAN } & \multirow[b]{2}{*}{ SD } & \multirow[b]{2}{*}{$\mathrm{cV} \%$} & \multirow[b]{2}{*}{ MIN } & \multirow[b]{2}{*}{ MAX } & \multicolumn{2}{|c|}{ 95\% Confidence Interva } \\
\hline & & & & & & Lower & Upper \\
\hline $\mathrm{BH}(\mathrm{cm})$ & 174.31 & 7.47 & 4.29 & 160.30 & 189.60 & 171.61 & 177.10 \\
\hline BM (kg) & 67.09 & 10.33 & 15.40 & 49.20 & 95.40 & 63.60 & 71.09 \\
\hline $\operatorname{BMI}\left(\mathrm{kg} / \mathrm{m}^{2}\right)$ & 22.01 & 2.60 & 11.81 & 16.94 & 30.11 & 21.15 & 23.01 \\
\hline $\mathrm{BFM}(\mathrm{kg})$ & 15.04 & 4.92 & 32.71 & 5.80 & 29.00 & 13.44 & 16.79 \\
\hline SMM (kg) & 28.98 & 4.16 & 14.35 & 22.70 & 37.70 & 27.60 & 30.52 \\
\hline BFM\% (\%) & 22.07 & 4.79 & 21.70 & 11.79 & 30.40 & 20.53 & 23.66 \\
\hline SMM\% (\%) & 43.33 & 2.79 & 6.44 & 38.34 & 49.60 & 42.40 & 44.25 \\
\hline BFMI & 4.94 & 1.56 & 31.58 & 2.00 & 9.15 & 4.44 & 5.49 \\
\hline SMMI & 9.50 & 0.92 & 9.68 & 8.16 & 11.90 & 9.18 & 9.87 \\
\hline $\mathrm{IH}$ & 1.00 & 0.17 & 17.00 & 0.62 & 1.32 & 0.94 & 1.06 \\
\hline PROTEIN (kg) & 10.27 & 1.38 & 13.44 & 8.20 & 13.20 & 9.81 & 10.79 \\
\hline PFI & 0.74 & 0.23 & 31.13 & 0.46 & 1.47 & 0.67 & 0.83 \\
\hline PIR & 7.26 & 8.43 & 116.12 & -1.25 & 29.00 & 4.43 & 10.35 \\
\hline
\end{tabular}

BH - body height; BM - body mass; BMI - body mass index; BFM - body fat mass; SMM - skeletal muscle mass; BFM\% percentage body fat mass; SMM\% - percentage skeletal muscle mass; BFMI - body fat mass index; SMMI - skeletal muscle mass index; IH - index of hypokinesy; PROTEIN - protein; PFI - protein-fat index; PIR - performance index rating.

Table II. Descriptive statistics - Guard (positions 1 and 2).

\begin{tabular}{lccccccc}
\hline \multirow{2}{*}{ VARIABLES } & MEAN & SD & cV\% & MIN & MAX & \multicolumn{2}{c}{ 95\% Confidence Interval } \\
& & & & & & Lower & Upper \\
\hline BH $(\mathrm{cm})$ & 169.83 & 5.56 & 3.27 & 160.30 & 178.50 & 166.89 & 172.54 \\
BM $(\mathrm{kg})$ & 62.95 & 9.82 & 15.60 & 49.20 & 78.70 & 57.79 & 68.46 \\
BMI $\left(\mathrm{kg} / \mathrm{m}^{2}\right)$ & 21.78 & 2.93 & 13.45 & 16.94 & 28.08 & 20.36 & 23.45 \\
BFM $(\mathrm{kg})$ & 13.08 & 4.57 & 34.94 & 5.80 & 22.50 & 10.85 & 15.68 \\
SMM (kg) & 27.85 & 3.60 & 12.93 & 23.30 & 34.20 & 25.99 & 29.78 \\
BFM\% (\%) & 20.30 & 4.41 & 21.72 & 11.79 & 28.63 & 18.05 & 22.69 \\
SMM\% (\%) & 44.44 & 2.16 & 4.86 & 40.59 & 48.37 & 43.27 & 45.55 \\
BFMI & 4.53 & 1.56 & 34.44 & 2.00 & 8.04 & 3.79 & 5.42 \\
SMMI & 9.63 & 0.94 & 9.76 & 8.20 & 11.40 & 9.17 & 10.16 \\
IH & 0.93 & 0.12 & 12.90 & 0.70 & 1.09 & 0.86 & 0.98 \\
PROTEIN (kg) & 9.89 & 1.20 & 12.13 & 8.40 & 12.00 & 9.28 & 10.53 \\
PFI & 0.83 & 0.25 & 29.99 & 0.50 & 1.47 & 0.70 & 0.98 \\
PIR & 9.04 & 10.54 & 116.59 & -1.00 & 29.00 & 3.44 & 15.02 \\
\hline
\end{tabular}

BH - body height; BM - body mass; BMI - body mass index; BFM - body fat mass; SMM - skeletal muscle mass; BFM\% percentage body fat mass; SMM\% - percentage skeletal muscle mass; BFMI - body fat mass index; SMMI - skeletal muscle mass index; IH - index of hypokinesy; PROTEIN - protein; PFI - protein-fat index; PIR - performance index rating.

Table III. Descriptive statistics - Forwards (positions 3 and 4).

\begin{tabular}{lccccccc}
\hline \multirow{2}{*}{ VARIABLES } & MEAN & SD & cV\% & MIN & MAX & \multicolumn{2}{c}{ 95\% Confidence Inter val } \\
& & & & & & Lower & Upper \\
\hline BH $(\mathrm{cm})$ & 174.05 & 6.33 & 3.64 & 164.20 & 183.80 & 170.28 & 177.47 \\
BM $(\mathrm{kg})$ & 67.65 & 10.66 & 15.76 & 54.50 & 95.40 & 62.37 & 74.49 \\
BMI $(\mathrm{kg} / \mathrm{m})$ ) & 22.29 & 2.94 & 13.19 & 19.71 & 30.11 & 20.88 & 24.07 \\
BFM $(\mathrm{kg})$ & 15.89 & 5.42 & 34.11 & 10.40 & 29.00 & 13.15 & 19.23 \\
SMM (kg) & 28.75 & 4.91 & 17.08 & 22.70 & 37.70 & 26.19 & 31.65 \\
BFM\% (\%) & 23.30 & 5.58 & 23.95 & 13.87 & 30.40 & 20.25 & 26.38 \\
SMM\% (\%) & 42.52 & 3.56 & 8.37 & 38.34 & 49.60 & 40.62 & 44.59 \\
BFMI & 5.28 & 1.83 & 34.66 & 3.08 & 9.15 & 4.31 & 6.35 \\
SMMI & 9.44 & 1.12 & 11.86 & 8.16 & 11.90 & 8.86 & 10.11 \\
IH & 1.04 & 0.21 & 20.19 & 0.62 & 1.31 & 0.92 & 1.15 \\
PROTEIN (kg) & 10.20 & 1.63 & 15.98 & 8.20 & 13.20 & 9.35 & 11.16 \\
PFI & 0.70 & 0.25 & 36.23 & 0.46 & 1.25 & 0.57 & 0.85 \\
PIR & 6.46 & 8.67 & 134.21 & -1.25 & 26.50 & 2.21 & 11.82 \\
\hline
\end{tabular}

BH - body height; BM - body mass; BMI - body mass index; BFM - body fat mass; SMM - skeletal muscle mass; BFM\% - percentage body fat mass; SMM\% - percentage skeletal muscle mass; BFMI - body fat mass index; SMMI - skeletal muscle mass index; IH - index of hypokinesy; PROTEIN - protein; PFI - protein-fat index; PIR - performance index rating. 
Table IV. Descriptive statistics - Centre (position 5).

\begin{tabular}{lccccccc}
\hline \multirow{2}{*}{ VARIABLES } & MEAN & SD & cV\% & MIN & MAX & 95\% Confidence Interval \\
& & & & & & Lower & Upper \\
\hline BH $(\mathrm{cm})$ & 182.43 & 5.35 & 2.93 & 175.70 & 189.60 & 178.93 & 186.11 \\
BM $(\mathrm{kg})$ & 73.31 & 8.31 & 11.34 & 64.80 & 90.50 & 68.50 & 79.93 \\
BMI $\left(\mathrm{kg} / \mathrm{m}^{2}\right)$ & 21.98 & 1.53 & 6.96 & 20.78 & 25.20 & 21.15 & 23.15 \\
BFM $(\mathrm{kg})$ & 17.09 & 4.00 & 23.41 & 13.60 & 23.60 & 14.56 & 19.97 \\
SMM $(\mathrm{kg})$ & 31.27 & 3.29 & 10.52 & 27.80 & 37.50 & 29.24 & 33.74 \\
BFM\% $(\%)$ & 23.15 & 3.59 & 15.51 & 19.65 & 29.57 & 20.89 & 25.78 \\
SMM\% $(\%)$ & 42.72 & 1.95 & 4.56 & 39.25 & 44.85 & 41.32 & 43.93 \\
BFMI & 5.11 & 1.05 & 20.55 & 4.14 & 6.63 & 4.46 & 5.85 \\
SMMI & 9.38 & 0.57 & 6.08 & 8.80 & 10.44 & 9.02 & 9.80 \\
IH & 1.05 & 0.14 & 13.33 & 0.90 & 1.32 & 0.97 & 1.15 \\
PROTEIN (kg) & 11.03 & 1.10 & 9.97 & 9.90 & 13.10 & 10.33 & 11.84 \\
PFI & 0.67 & 0.12 & 18.50 & 0.47 & 0.80 & 0.58 & 0.74 \\
PIR & 5.44 & 1.90 & 34.93 & 2.00 & 8.00 & 4.19 & 6.63 \\
\hline
\end{tabular}

BH - body height; BM - body mass; BMI - body mass index; BFM - body fat mass; SMM - skeletal muscle mass; BFM\% - percentage body fat mass; SMM\% - percentage skeletal muscle mass; BFMI - body fat mass index; SMMI - skeletal muscle mass index; IH - index of hypokinesy; PROTEIN - protein; PFI - protein-fat index; PIR - performance index rating.

Table V. Pearson Correlation.

\begin{tabular}{lcccc}
\hline VARIABLES & $\begin{array}{c}\text { All players } \\
(\mathrm{n}=30)\end{array}$ & $\begin{array}{c}\text { Guards } \\
(\mathrm{n}=12)\end{array}$ & $\begin{array}{c}\text { Forwards } \\
(\mathrm{n}=11)\end{array}$ & $\begin{array}{c}\text { Centres } \\
(\mathrm{n}=7)\end{array}$ \\
\hline BH $(\mathrm{cm})$ & 0.13 & 0.22 & 0.52 & 0.16 \\
BM $(\mathrm{kg})$ & 0.06 & 0.05 & 0.24 & 0.45 \\
BMI $\left(\mathrm{kg} / \mathrm{m}^{2}\right)$ & -0.01 & -0.04 & 0.01 & 0.57 \\
BFM $(\mathrm{kg})$ & -0.19 & -0.04 & -0.35 & 0.62 \\
SMM $(\mathrm{kg})$ & 0.24 & 0.10 & 0.58 & 0.24 \\
BFM\% $(\%)$ & -0.33 & -0.06 & $\mathbf{- 0 . 6 5 *}$ & 0.57 \\
SMM\% $(\%)$ & $\mathbf{0 . 4 0} *$ & 0.10 & $\mathbf{0 . 7 2} * *$ & -0.52 \\
BFMI & -0.23 & -0.07 & -0.43 & 0.64 \\
SMMI & 0.25 & 0.01 & 0.51 & 0.24 \\
IH & $\mathbf{- 0 . 4 3 *}$ & -0.06 & $\mathbf{- 0 . 8 1} * *$ & 0.37 \\
PROTEIN $(\mathrm{kg})$ & 0.25 & 0.11 & 0.58 & 0.24 \\
PFI & $\mathbf{0 . 3 6} *$ & 0.06 & $\mathbf{0 . 7 4 * *}$ & -0.51 \\
\hline
\end{tabular}

$\mathrm{p}<0.01^{* *} ; \mathrm{p}<0.05^{*} \mathrm{BH}$ - body height; BM - body mass; BMI - body mass index; BFM - body fat mass; SMM - skeletal muscle mass; BFM\% - percentage body fat mass; SMM\% - percentage skeletal muscle mass; BFMI - body fat mass index; SMMI - skeletal muscle mass index; IH - index of hypokinesy; PROTEIN - protein; PFI - protein-fat index; PIR - performance index rating.

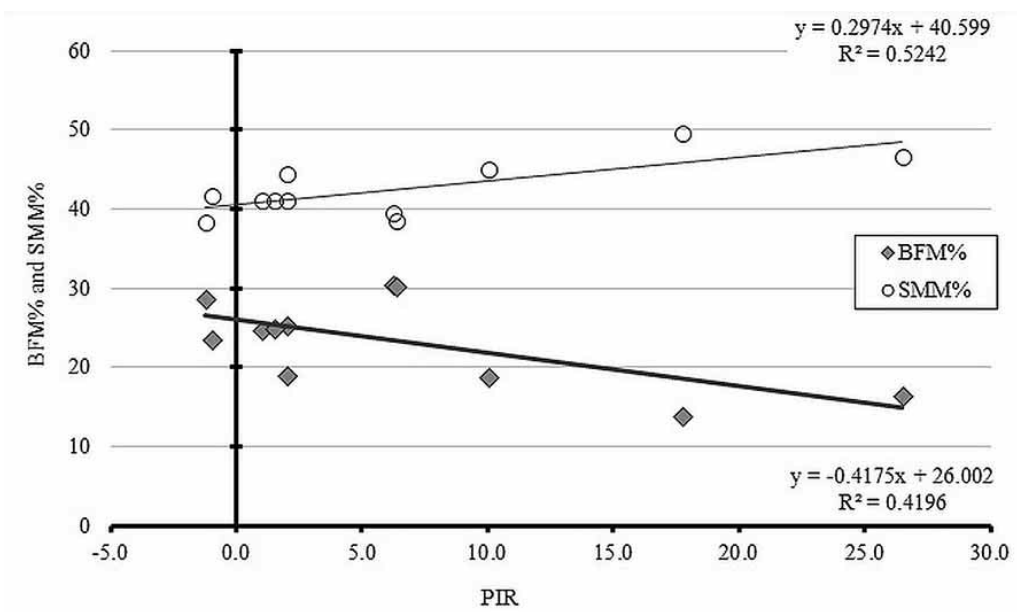

\section{DISCUSSION}

The aim of this research was to investigate the correlation of morphological characteristics, which is body composition characteristics with the competitive performance of female basketball players of cadet age (U16) in general and depending on the position played in the basketball team (guards, forwards, centre).

The obtained results of morphological characteristics were compared with the results of previous studies completed on basketball players up to the age of 16 years (U16). In a study published by Drinkwater et al. (2008),

Fig. 1. Linear regression analysis: Relation between criteria (PIR) and predictive body composition variables (BFM\% and SMM\%) at forward position female basketball players.

BFM\% - percentage body fat mass; SMM\% percentage skeletal muscle mass; PIR - performance index rating. 


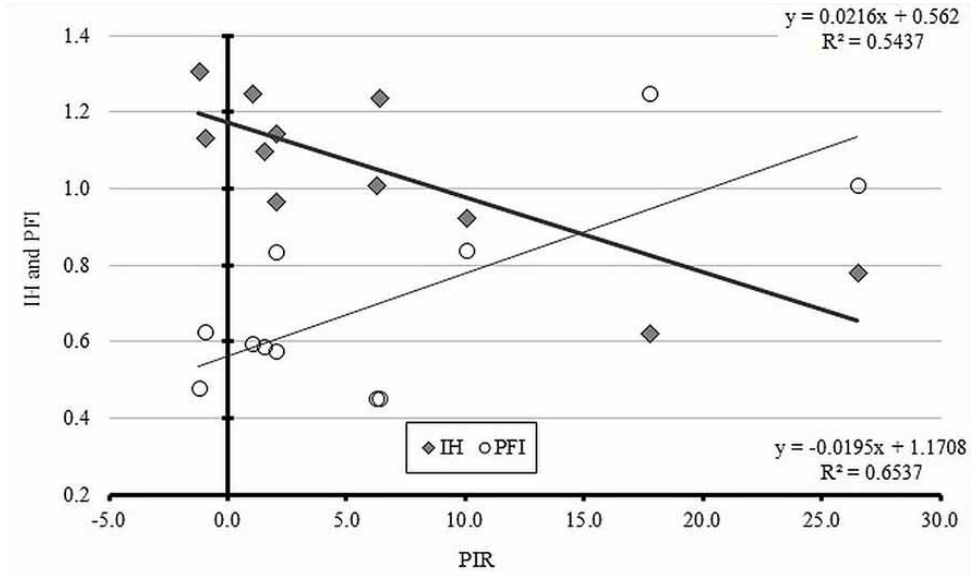

Fig. 2. Linear regression analysis: Relation between criteria (PIR) and predictive body composition variables (IH and PFI) at forward position female basketball players

IH - index of hypokinesy; PFI protein-fat index; PIR - performance index rating. basketball players in the Australian state (U16) were thus: height and weight $(166.2 \mathrm{~cm}, 57.8 \mathrm{~kg}$ at Point Guard, 169.4 $\mathrm{cm}, 61.6 \mathrm{~kg}$ in the Off Guard position, $173.5 \mathrm{~cm}, 64.1 \mathrm{~kg}$ Small Forward, $177.4 \mathrm{~cm}, 69.4 \mathrm{~kg}$ in the Power Forward position and $181.6 \mathrm{~cm}, 70.5 \mathrm{~kg}$ in the Centre position). These are almost identical to the sample of basketball players in this research (Guards position $169.83 \mathrm{~cm}, 62.95$ $\mathrm{kg}$; Forward position $174.05 \mathrm{~cm}, 67.65 \mathrm{~kg}$; Centre 182.43 $\mathrm{cm}, 73.31 \mathrm{~kg}$ ). While in the research published by FortVanmeerhaeghe et al. (2016), basketball players from Spain, aged up to 16 years (U16), are slightly taller and heavier than the basketball players from this research (180 $\pm 8.00 \mathrm{~cm}$ vs. $174.31 \pm 7.47 \mathrm{~cm} ; 72.30 \pm 14.30 \mathrm{~kg}$ versus $67.09 \pm 10.33 \mathrm{~kg}$ ). Additionally, they also have a lower fat percentage $(15.66 \pm 3.31$ vs. $22.07 \pm 4.79)$ than the sample of players in this study. Matching the height and weight of players from Spain are the basketball players of the national (U16) women's team in Italy. Pizzigalli et al. (2017) state that players (U16) of the national women's basketball team of Italy are $180.4 \pm 7.2 \mathrm{~cm}$ high, $72.5 \pm$ 8.1 weight and have BMI $22.2 \pm 2.2 \mathrm{~kg} / \mathrm{m}^{2}$. The difference in the weight and height of Italian basketball players, compared to the players in this study, can be explained by the fact that the sample who participated in this research are from the system of the cadet (U16) national league of Serbia, while the Italian basketball players were a sample selection from the Basketball Association of Italy.

Based on the results of the Pearson Correlation Analysis, which was developed for the purpose of determining the degree of connection between the dependent variable (variables of Match Performance Analysis) and independent variables (variables of morphological and physical characteristics), it can be seen that at general level competitive performance is associated with variables: percentage skeletal muscle mass, index of hypokinesy and protein-fat index $(\mathrm{SMM} \% \mathrm{r}=0.40, \mathrm{p}=$ 0.03 ; IH r $=-0.43, \mathrm{p}=0.02$; PFI $\mathrm{r}=0.36, \mathrm{p}=0.05$, Table
V). This suggests that those basketball players who have a higher percentage of muscle mass, a smaller index of hypokinesy (a lower percentage of body fat mass compared to a body mass index) and a higher protein-fat index (higher protein ratio than body fat mass) are more competitive in a basketball game, that is, they have a bigger PIR than basketball players that do not feature these morphological characteristics. The assumption is that in younger basketba11 categories there is no homogeneity in the group in the sense that the basketball players have not reached their biological potential as regards the development of morphological characteristics. Therefore, those that are biologically mature and more developed are physically more capable than those who lag behind in terms of biological development. Given that today's basketball players, from cadets (U16) to the top players, must be strong enough to play one on one and taking into account that the strength of the upper part of the body plays an important role in dominating the field (Zaric' et al.), it is logical that muscle mass is an important factor that affects the competitive performance of basketball players.

From the point of view of the positions in the team, the statistically significant relationship between the independent and the dependent variable was recorded only in the Forwards position (BFM\% $\mathrm{r}=-0.65, \mathrm{p}=0.03$; SMM\% $\mathrm{r}=0.72, \mathrm{p}=0.01 ; \mathrm{IH} \mathrm{r}=-0.81, \mathrm{p}=0.00 ;$ PFI $\mathrm{r}=$ $0.74, \mathrm{p}=0.01$; Table V; Figures 1 and 2). Competitive and successful forwards are distinguished by a small percentage of body fat mass, a higher percentage of muscle mass, a smaller hypokinesy index (a lower percentage of body fat mass versus body mass index) and a larger protein-fat index (a higher protein ratio than body fat mass). Pehar et al. in their research say that basketball players at the elite level of the first and second divisions differ by the percentage of body fat mass, that is, basketball players of the first division have a lower percentage of body fat mass compared to basketball players of the second division. 
Reaching the same conclusion Ramos et al. state that basketball players up to 14 years of age (U14) from betterranked elite basketball teams have a lower percentage of body fat than players from lower ranked clubs of the same level of competition. This means that fatty tissue is a factor that disturbs the activity of female and male basketball players.

On the basis of the obtained results, it can be assumed that due to insufficient competitive experience and, due to the consequent technical-tactical level of training adequate in relation to the age range, where the final phase of specialisation in relation to the position in the game is still not completed, basketball players in the forward position (forwards are on average $174.05 \mathrm{~cm}$ high and $67.65 \mathrm{~kg}$ weight (Table III), which corresponds to the average basketball player at the general level $(\mathrm{BH}=174.31 \mathrm{~cm}$ and $\mathrm{BM}$ $=67.09 \mathrm{~kg}$, Table $\mathrm{I}$ in relation to the constitution of basketball players in other positions (Table II, Guards: $\mathrm{BH}=$ $169.83 \mathrm{~cm}, \mathrm{BM}=62.95 \mathrm{~kg}$, Table IV, Centres: $\mathrm{BH}=182.43$ $\mathrm{cm}, \mathrm{BM}=73.31 \mathrm{~kg}$ ), can play in all positions and at the same time be basketball players who are most responsible for results in the cadet (U16) category of the competition. Therefore, it is essential that these basketball players, in addition to suitable technical-tactical training and achieving the optimal level of development of physical performance, are also athletic builds so that they can best demonstrate performances in basketball matches on which the competitive result depends (Garcia-Gil et al.).

The results of research done with athletes from other collective sports are in accordance with the results of this research. Bankovic et al. conclude that the volleyball players who won the silver medal at the Olympic Games in Rio 2016 were mainly characterised by a very high muscle mass $(\mathrm{SMM} \%=48.95 \pm 1.78)$ and a small amount of body fat that was close to the biological minus for women (BFM\% $=$ $13.43 \pm 2.70$ ). Also, Copic et al. (2014) in their research showed that muscle mass and body fat is an important predictor for expressing specific performance in volleyball. In research conducted with the National Football League (NFL) players aged 20 to 24, Provencher et al. (2018) found that the draft players had a significantly lower percentage of fat compared to players who were not drafted. Furthermore, a higher percentage of fat translates into lower chances of becoming drafted. The influence of morphological characteristics, as a predictor of the competitive performance of athletes from several sporting areas, generally indicates their importance and the need for research in this field. Elite athletes need to optimise their body composition to deliver world-class performances (Banda et al., 2019).

The practical application of this research can be seen in the system of control of applied training work, then the selection, as well as in the creation of modelling morphological characteristics of cadet (U16) basketball players. Since there are a small number of studies on this topic that have a direct practical application, it is necessary to continue with further research in order to define the optimal morphological model of basketball players of cadet age (U16), both at the general level and in particular team positions in order to select and predict competitive performance.

\section{ACKNOWLEDGMENTS}

The study was partly supported by the grant III47015 of the Research Council of the Republic of Serbia.

ZARIC, I.; DOPSAJ, M.; MARKOVIC, M.; ZARIC, M.; JAKOVLJEVIC, S. \& BERIC, D. Características de la composición corporal medidas por bioimpedancia multicanal en jóvenes jugadoras de baloncesto: relación con el rendimiento del partido. Int. J. Morphol., 38(2):328-335, 2020.

RESUMEN: El objetivo del estudio fue investigar la correlación entre las características morfológicas, es especial, las características de la composición corporal y el rendimiento competitivo de jugadoras de baloncesto cadetes, en general y en cada posición en el equipo. La investigación incluyó a las jugadoras de baloncesto femenino U16 de los tres mejores clubes de Primera Liga de Cadetes de Serbia $(\mathrm{N}=30)$. Esta investigación consistió en medir las características de la composición corporal, como un espacio de variables independientes, y el análisis de actividades competitivas, donde la variable dependiente representa el nivel de rendimiento competitivo alcanzado. Sobre la base de los resultados del análisis de coeficiente de correlación de Pearson, que se realizó con el propósito de determinar el grado de conexión entre la variable dependiente y las variables independientes, se pudo observar que, en general, el rendimiento competitivo está vinculado a las variables: porcentaje de masa muscular esquelética, índice de hipocinesia e índice proteínagrasa. Desde el punto de vista de posiciones dentro de un equipo de baloncesto, la relación estadísticamente importante entre la variable independiente y la variable dependiente ha sido registrada solamente en la posición de delantero. Las jugadoras delanteras más exitosas y competitivas se distinguen por un bajo porcentaje de grasa en su masa corporal, así como un mayor porcentaje de masa muscular, un índice de hipocinesia más bajo y un índice proteína-grasa más alto. El uso práctico de esta investigación se puede ver en el sistema de control del trabajo de entrenamiento aplicado, luego en la selección, así como en la creación de modelos de características morfológicas de jugadoras en la categoría cadetes (U16).

PALABRAS CLAVE: Baloncesto; Índice de rendimiento; Mujeres Deportistas; Morfología; Antropometría. 


\section{REFERENCES}

Banda, M.; Grobbelaar, H. W. \& Terblanche, E. Body composition and somatotypes of male Zimbabwean Premier League Football referees. J. Sports Med. Phys. Fitness, 59(3):434-9, 2019.

Bankovic, V.; Dopsaj, M.; Terzic, Z. \& Nesic, G. Descriptive body composition profile in female olympic volleyball medalists defined using multichannel bioimpedance measurement: Rio 2016 team case study. Int. J. Morphol., 36(2):699-708, 2018.

Bompa, T. \& Buzzichelli, C. Periodization Training for Sports. $3^{\text {rd }}$ ed. Champaingn (IL), Human Kinetics, 2015.

Carter, J. E. L.; Ackland, T. R.; Kerr, D. A. \& Stapff, A. B. Somatotype and size of elite female basketball players. J. Sports Sci, 23(10):1057-63, 2004.

Copic, N.; Dopsaj, M.; Ivanovic, J.; Nesic, G. \& Jaric, S. Body Composition and muscle strength predictors of jumping performance: differences between elite female volleyball competitors and nontrained individuals. J. Strength Cond. Res., 28(10):2709-16, 2014.

Dopsaj, M.; Markovic, M.; Kasum, G.; Jovanovic, S.; Koropanovski, N.; Vukovic, M. \& Mudric, M. Discrimination of different body structure indexes of elite athletes in combat sports measured by multi frequency bioimpedance method. Int. J. Morphol., 35(1):199-207, 2017.

Drinkwater, E. J.; Pyne, D. B. \& McKenna, M. J. Design and interpretation of anthropometric and fitness testing of basketball players. Sports Med, 38(7):565-78, 2008.

Fort-Vanmeerhaeghe, A.; Montalvo, A.; Latinjak, A. \& Unnithan, V. Physical characteristics of elite adolescent female basketball players and their relationship to match performance. J. Hum. Kinetics, 53:167-78, 2016.

Garcia-Gil, M.; Torres-Unda, J.; Esain, I.; Duñabeitia, I.; Gil, S. M.; Gil, J. \& Irazusta, J. Anthropometric parameters, age, and agility as performance predictors in elite female basketball players. J. Strength Cond. Res., 32(6):1723-30, 2018.

Hoare, D. G. Predicting success in junior elite basketball players--The contribution of anthropometic and physiological attributes. J. Sci. Med. Sport, 3(4):391-405, 2000.

Ibáñez, S. J.; García, J.; Feu, S.; Lorenzo, A. \& Sampaio, J. Effects of consecutive basketball games on the game-related statistics that discriminate winner and losing teams. J. Sports Sci. Med., 8(3):45862, 2009.

Kukic, F.; Dopsaj, M.; Dawes, J.; Orr, R. \& Cvorovic, A. Use of human body morphology as an indication of physical fitness: implications for police officers. Int. J. Morphol., 36(4):1407-12, 2018.

Malina, R. M.; Bouchard, C. \& Bar-Or, O. Growth, Maturation, and Physical Activity. $2^{\text {nd }}$ ed. Champaign (IL), Human Kinetics, 2004.

Norton, K. \& Olds, T. Morphological evolution of athletes over the 20th century: causes and consequences. Sports Med., 31(11):763-83, 2001.

Ochoa Martínez, P. Y.; Hall López, J. A.; Alarcón Meza, E. I.; Arráyales Millán, E. -M. \& Sánchez León, R. Somatotype profile and body composition of players from the Mexican Professional Basketball League. Int. J. Morphol., 32(3):1032-5, 2014.

Pehar, M.; Sekulic, D.; Sisic, N.; Spasic, M.; Uljevic, O.; Krolo, A.; Milanovic, Z. \& Sattler, T. Evaluation of different jumping tests in defining position-specific and performance-level differences in high level basketball players. Biol. Sport, 34(3):263-72, 2017.

Pizzigalli, L.; Cremasco, M. M.; La Torre, A.; Rainoldi, A. \& Benis, R. Hand grip strength and anthropometric characteristics in Italian Female National Basketball Teams. J. Sports Med. Phys. Fitness, 57(5):521-8, 2017.

Provencher, M. T.; Chahla, J.; Sanchez, G.; Cinque, M. E.; Kennedy, N. I.; Whalen, J.; Price, M. D.; Moatshe, G. \& LaPrade, R. F. Body mass index versus body fat percentage in prospective National Football League athletes: overestimation of obesity rate in athletes at the National Football League scouting combine. J. Strength Cond. Res, 32(4):1013$9,2018$.
Ramos, S.; Volossovitch, A.; Ferreira, A. P.; Barrigas, C.; Fragoso, I. \& Massuça, L. Differences in maturity, morphological and fitness attributes between the better- and lower-ranked male and female U-14 Portuguese elite regional basketball teams. J. Strength Cond. Res., 2018. doi: 10.1519/JSC.0000000000002691. In press.

Sampaio, J.; Janeira, M.; Ibáñez, S. \& Lorenzo, A. Discriminant analysis of game-related statistics between basketball guards, forwards and centres in three professional leagues. Eur. J. Sport Sci., 6(3):173-8, 2006.

Tanner, R. K. \& Gore, C. J. Physiological Tests for Elite Athletes. $2^{\text {nd }}$ ed. Champaign (IL), Human Kinetics, 2013.

Thomas, J. R.; Silverman, S. \& Nelson, J. Research Methods in Physical Activity. $7^{\text {th }}$ ed. Champaign (IL), Human Kinetics, 2015.

Zaric, I.; Dopsaj, M. \& Markovic, M. Match performance in young female basketball players: relationship with laboratory and field tests. Int. J. Perform. Anal. Sport, 18(1):90-103, 2018.

Ziv, G. \& Lidor, R. Physical attributes, physiological characteristics, oncourt performances and nutritional strategies of female and male basketball players. Sports Med., 39(7):547-68, 2009.

\section{Corresponding Author: \\ Ivan Zaric}

Faculty of Sport and Physical Education

University of Belgrade

Blagoja Parovic'a 156

SERBIA

Email: info@ivanzaric.com

ORCID 0000-0002-9003-6028

Received: 05-08-2019

Accepted: 23-09-2019 